\title{
Clevidipine Butyrate Injectable Emulsion
}

National Cancer Institute

\section{Source}

National Cancer Institute. Clevidipine Butyrate Injectable Emulsion. NCI Thesaurus. Code C88036.

An injectable phospholipid emulsion containing the butyrate salt of the synthetic, shortacting, dihydropyridine L-type calcium channel antagonist clevidipine with antihypertensive activity. Clevidipine specifically binds to calcium channels in vascular smooth muscle cells, inhibiting the influx of extracellular calcium ions into vascular smooth muscle cells. This results in dilatation of systemic arteries, a decrease in systemic vascular resistance and so a decrease in arterial blood pressure. This agent is metabolized by esterases in the blood and extravascular tissues to an inactive carboxylic acid metabolite. 